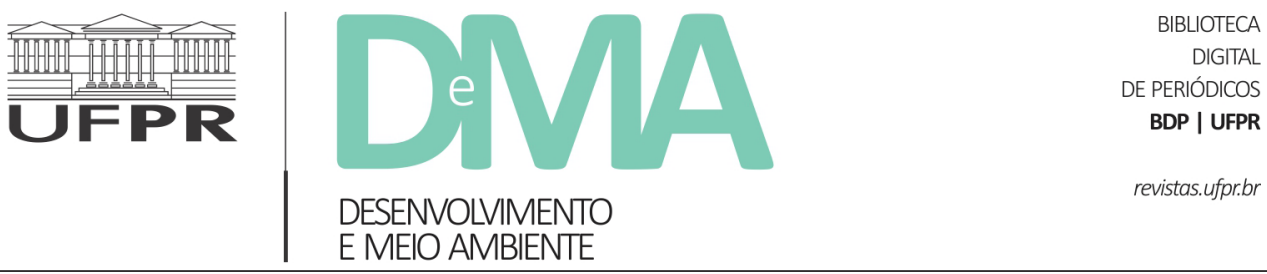

\title{
"A gente acostuma os olhos": pescadores artesanais de tarrafa e botos-de-Lahille nas paisagens da Barra do Rio Tramandaí
}

\section{"Our eyes grow accustomed": artisanal fishermen with casting nets and Lahille's bottlenose dolphin in the landscapes of the Tramandaí River inlet}

\author{
Emanuelly SILVA ${ }^{1 *}$, Flávio Leonel Abreu da SILVEIRA², Olavo Ramalho MARQUES ${ }^{1}$, Ignacio Benites \\ MORENO ${ }^{1,3,4}$ \\ ${ }^{1}$ Universidade Federal do Rio Grande do Sul (UFRGS), Porto Alegre, RS, Brasil. \\ ${ }^{2}$ Universidade Federal do Pará (UFPA), Belém, PA, Brasil. \\ ${ }^{3}$ Universidade Federal do Rio Grande do Sul (UFRGS), Tramandaí, RS, Brasil. \\ ${ }^{4}$ Centro de Estudos Costeiros Limnológicos e Marinhos (CECLIMAR), Universidade Federal do Rio Grande do Sul (UFRGS), Imbé, RS, Brasil. \\ *E-mail de contato: emanuellybio@gmail.com
}

Artigo recebido em 2 de abril de 2020, versão final aceita em 28 de agosto de 2020, publicado em 26 de março de 2021.

RESUMO: Enquanto unidade que dialoga com a ideia geográfica de espaço ou território, a paisagem é um conceito multifacetado que nos auxilia no entendimento das interações entre distintos grupos animais e das expressões culturais humanas. Estudos das relações entre pessoas e natureza atuam como instrumentos de compreensão das afetividades e percepções que envolvem complexas teias de relações, o que nos possibilita encontrar nexos relacionais entre humanos e não humanos para pensarmos numa unidade dinâmica a partir de ambos. No Sul do Brasil, ocorre uma peculiar interação entre humanos e não humanos: a pesca cooperativa. Prática ritualizada e tradicional que consagra a Barra de Tramandaí como uma das duas localidades mundiais onde sistematicamente esse fenômeno acontece. Os botos Tursiops gephyreus e pescadores artesanais de tarrafa cooperam na pesca. O boto sinaliza o momento apropriado para os pescadores jogarem suas tarrafas na água, o que otimiza a atividade de pesca e a energia despendida por ambos. A área de estudo localiza-se na "Barra", um estuário no Litoral Norte do Rio Grande do Sul. O artigo propõe um diálogo entre disciplinas distintas: reunindo os campos biológico e antropológico, através da inquirição de como se dá a cooperação entre cetáceo e ser humano, analisando como os pescadores praticam as paisagens em que estão inseridos. A coleta de dados aliou a observação participante junto aos pescadores a um questionário livre semiestruturado. Através de análise qualitativa dos resultados, podemos inferir que as manifestações bioculturais presentes nas vivências dos pescadores se dão em como eles observam, sentem e leem a paisagem. São experiências portadoras de significados, em que leituras individuais de cada pescador sobre o contexto praticado ressoam transformando-se num conhecimento coletivo e compartilhado, pois entre os pescadores é visto como um 
domínio de códigos, quanto à interação com os botos e o relato das mesmas dificuldades de manutenção desse fenômeno interespécies.

Palavras-chave: pesca cooperativa; pescadores artesanais; paisagem; botos; Litoral Norte Gaúcho; Barra do Rio Tramandaí.

ABSTRACT: A landscape is a unit that dialogues with the geographical idea of space, either of a territory or region, and is a multifaceted concept that assists in the understanding of interactions between different animal groups and expressions of human culture. Studies on the relationships between people and nature act as instruments to comprehend the affections and perceptions that envelop complex networks, which allows us to find relational nexus between humans and non-humans, such that we are able to reflect on a dynamic unit considering both. A peculiar interaction between humans and non-humans takes place along the coast of the state of Rio Grande do Sul, in southern Brazil: cooperative fishing. A traditional and ritualized practice, the Tramandai River inlet is one of only two places in the world where this occurs. Lahille's bottlenose dolphin, Tursiops gephyreus, and artisanal fishermen with casting nets cooperate in the mullet (Mugil liza) fisheries. Dolphins signal the appropriate moment for fishers to throw their nets in the water, optimizing the fishing activity and the energy spent by both groups. The study area is the Tramandaí River inlet, an estuarine environment in the northern coast of the state of Rio Grande do Sul. This study aimed to link biological and anthropological fields in the pursuit to understand biocultural manifestations of these interactions, from the familiarity with the artisanal fishermen community, who are part of the cooperative fishing. We aimed to understand how the fishers recognize the landscape they compose and the way they cooperatively coexist with these cetaceans. In addition to participant observation, a semi-structured and open questionnaire was applied. Results were analyzed taking on a qualitative approach. The landscape is perceived by these workers through (and based on) their meaningful experiences, which reverberate in their individual views about the space where they act and the affection they have over their practice and relationship with the dolphins.

Keywords: cooperative fishing; artisanal fisherman; landscape; dolphins; northern coast of Rio Grande do Sul; Tramandaí River Inlet.

Os autores gostariam de dedicar este trabalho à memória de Airton Gomes da Rosa, exímio pescador e grande amigo que nos deixou precocemente em 2019. 


\section{Introdução}

\subsection{As agências ${ }^{1}$ e singularidades do} fenômeno da pesca cooperativa na Barra do Rio Tramandaí

Sabe-se que, enquanto unidade que historicamente dialoga com a ideia geográfica de espaço, território ou região, o conceito (ou noção) de paisagem vem despertando novas perspectivas de reflexão nos debates e produções contemporâneas (Cabral, 2000). Na busca por um entendimento mais integral do que nos cerca, os estudos das relações entre pessoas e natureza atuam como instrumentos de compreensão das afetividades e percepções que envolvem teias de relações e possibilitam atravessar o limiar entre um [pessoa] e outro [natureza] para pensarmos em uma unidade dinâmica a partir de ambos (Tuan, 1983). Segundo Certeau (1994), a paisagem pode ser entendida como as ações materiais e imateriais e, ainda, as agências humanas e não humanas que constituem as experiências praticadas (Silveira, 2016). Trata-se, como defende Ferreira (1984), de "uma porção do espaço apreendida com o olhar". Porém, esse olhar não absorve apenas o que enxerga de fato, pois atribui significados ao que vê - ou seja, a paisagem vivenciada é também engendrada por aquele que a observa (Ronai, 1976) e, por isso, implica visões de mundo e sentimentos em relação a certo "recorte" do espaço e/ou da natureza, enfim, ao que se entende por paisagem, mediante uma visada que define uma parte no todo (Simmel, 1996).

De acordo com Collot (1990), as percepções de paisagem remetem a três fundamentos principais: 0 ponto de vista - já que o sujeito observador detém uma interioridade em relação ao que vê, não se separando do observado quando experiencia o que observa, e é diretamente atravessado por tal fenômeno. Por conseguinte, o elemento da parte traz o sentido de que o espaço observado é um fragmento de um todo maior, de um entrelaçamento de significados, e que as observações feitas pelo pesquisador não são restritas ao espaço em si, mas tomadas por suas experiências diretas (seu olhar particular sobre a paisagem); e suas experiências indiretas - formas de transmissão simbólica, por exemplo - onde estas se somam. E, por fim, a ideia de conjunto, quando, nas palavras do autor, a paisagem "fala a quem olha", pois atua como um simbolismo estético na medida em que cada indivíduo a percebe com um conjunto específico de elementos/aparatos que lhe chamam a atenção. É importante ressaltar que a paisagem excede o corpo e o olhar do observador, na medida em que ela é intrínseca a tudo que lhe compõe, a tudo que o atravessa de alguma forma, como sons, ventos, limites espaciais e interações com os outros.

Neste sentido, é a partir do narrado, ou do ato de narrar, que pretendemos aqui apresentar as agências dos trabalhadores artesanais que compõem

\footnotetext{
${ }^{1}$ Para a proposta deste artigo, tomamos a noção de agência humana e/ou não humana como um fenômeno que implica a necessidade de pensarmos as formas diversas como as ações dos seres se manifestam em dado contexto. Consideramos tanto as intencionalidades quanto as práticas de usos e manejos do mundo. As agentividades estariam, assim, presentes nos modos de vida dos entes em relação e indicariam as formas como conteúdos biossociais, assim como bioculturais, produzem conexões complexas entre os seres em interação nas paisagens. No caso em questão, a agência se dá mediante as interações entre "actantes híbridos" de cetáceos-humanos (Taylor \& Carter, 2012:2). Trata-se de um conceito abrangente. Quanto ao conceito de agência, apoiamo-nos, ainda, em autores como Ahearn (2000), Frank (2006) e Deshayes (2013).
} 
as paisagens de nosso estudo. Para tanto, propomos que ocupem os três fundamentos anteriormente citados da seguinte forma: 1) a pesca deve ser entendida como elemento central do ponto de vista dos pescadores artesanais na composição desta paisagem, a partir da relação com os botos da Barra; 2) que os pescadores, os botos da Barra e esse padrão não usual de relação entre espécies (especialmente no que tange ao comportamento dos golfinhos em sua interação com os humanos) atuem como a parte; e por fim, 3) que os saberes e fazeres envolvidos na leitura dos elementos da paisagem, na interação com os botos e no todo da pesca cooperativa (que aqui podemos chamar de conhecimento tradicional) ocupem o último fundamento, o conjunto.

É essencial salientar que a escolha de fundamentar os elementos citados nas três categorias de análise busca fornecer ao leitor uma visão ampla do fenômeno que aqui descrevemos, pois o diálogo entre os elementos mostra, justamente, que eles se agregam numa forma biocultural que move conteúdos singulares na configuração da chamada "pesca com o boto", ou, "corrida com o boto" no contexto da Barra do Rio Tramandaí.

\subsection{O contexto da pesquisa: a Barra do Rio}

\section{Tramandaí}

O litoral do Rio Grande do Sul apresenta o encontro de duas correntes marinhas: a Corrente das Malvinas, de origem subantártica e rica em nutrientes, e a Corrente do Brasil, de origem equatorial e que se desloca ao sul nos meses mais quentes (Seeliger \& Costa, 1998; Piola et al., 2005). As duas correntes, aliadas ao desague do Rio da Prata e da Lagoa dos Patos, tornam a região costeira gaúcha uma importante zona de alimentação para animais marinhos, uma vez que a área apresenta alta disponibilidade de matéria orgânica (Haimovici et al., 2006). As zonas de alimentação são frequentadas por vasta gama de animais diante da abundância de recursos e complexidade das cadeias tróficas, o que pode ser evidenciado pelos registros de ocorrência de fauna marinha no estado, com a presença confirmada de trinta e seis (36) (Würdig \& Freitas, 2009; Wickert et al., 2016) das quarenta e sete (47) espécies de cetáceos, por exemplo, que ocorrem na costa brasileira (Cyrpiano-Souza et al., 2017; Miranda et al., 2019).

As nascentes da Bacia do Rio Tramandaí são formadas a partir dos rios Três Forquilhas e Maquiné (Castro \& Mello 2013), inseridos no Bioma Mata Atlântica. Estuários são regiões de transição entre ambientes dulcícolas e marinhos, sendo considerados ecossistemas com significativa biodiversidade, além de importantes áreas de alimentação, reprodução e desenvolvimento de inúmeras espécies (Würdig \& Freitas, 2009). O estuário do Rio Tramandaí faz parte do complexo lagunar Tramandaí-Armazém, sob as coordenadas $29^{\circ} 58^{\prime}$ S; $50^{\circ} 07^{\prime}$ W. A Barra do Rio Tramandaí é por onde o estuário desemboca no oceano, e ponto no qual os municípios de Imbé e Tramandaí são delimitados, sendo a margem norte pertencente a Imbé, e a margem sul, pertencente a Tramandaí (Figura 1).

O Canal da Barra apresenta 1,5 quilômetros de comprimento e até 100 (cem) metros de largura (Santos et al., 2016). Nas margens do município de Imbé junto à Barra aparecem diversas edificações comerciais, como restaurantes e quiosques situados em uma via pavimentada para circulação e estacionamento de automóveis, o que configura uma estética urbana - ou mais antropizada - à 
paisagem, cujos usos direcionam-se a atividades lúdicas à beira mar. Mesmo a pesca realizada na margem norte da Barra é, em geral, mais lúdica, seja ela com vara de pesca, coca ou tarrafa. A margem de Tramandaí, por sua vez, mantém mais elementos de seu aspecto natural de praia, sendo composta por dunas, vegetação e o encontro das águas salobras com a areia, constituindo um cenário com ambiência menos antropizada, e onde os pescadores de tarrafa predominantemente se concentram para pescar em parceria com os botos.

Aquele ponto da Barra é praticado por diversos atores sociais, pois além dos pescadores, temos diversos usuários que participam das paisagens locais, que podem ser amigos e familiares dos pescadores; pessoas que pescam sem ter licença de pesca; pescadores amadores, além de surfistas e praticantes de outros esportes aquáticos, banhistas, turistas e veranistas, principalmente, nas estações mais quentes. Há, ainda, uma grande diversidade de aves e peixes que compõem as paisagens locais. Algumas espécies de aves são migratórias e ocorrem sazonalmente, oriundas tanto do hemisfério norte quanto do sul. Muitos peixes dependem da Barra para completar seus ciclos vitais (e.g., crescimento e/ou reprodução) (Camargo, 2020). Todos esses sujeitos interagem entre si e com o ambiente, pois nesta margem a proximidade entre eles é maior, já que representa uma faixa não muito larga de areia, o que possibilita uma visão ampliada da paisagem e suas agências nela. Portanto, é nessa margem que nosso estudo ${ }^{2}$ concentra seus esforços.
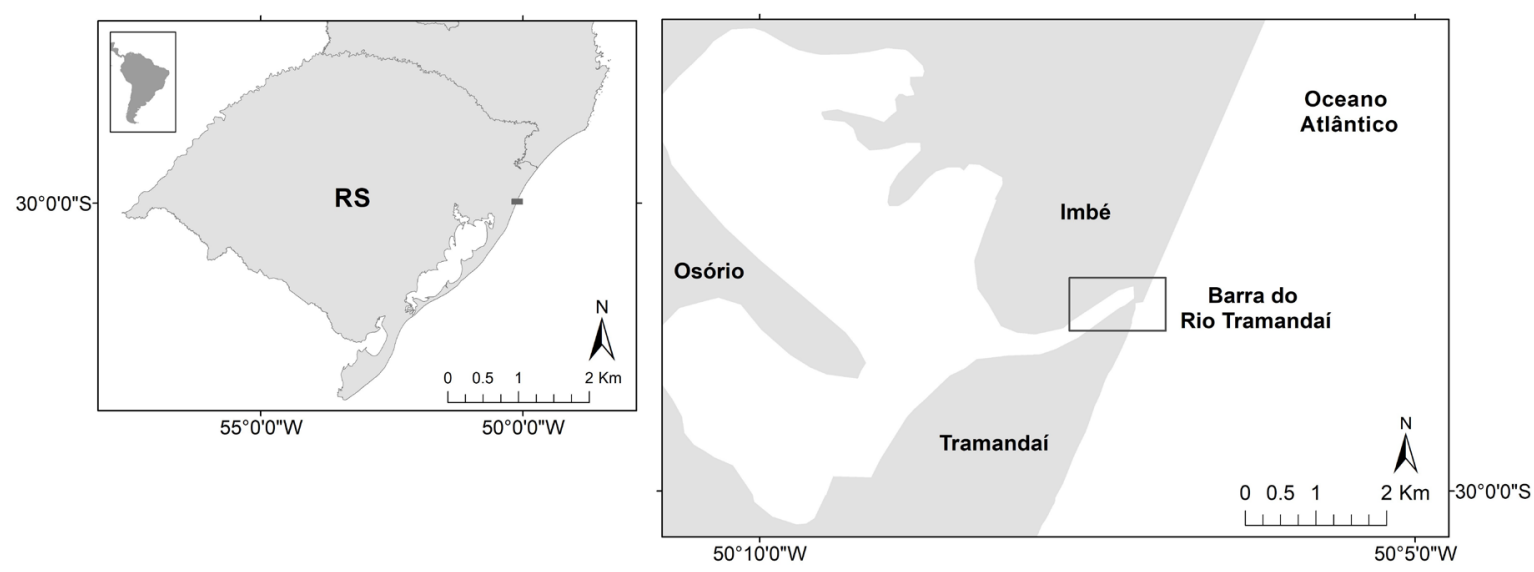

FIGURA 1 - A área de estudo localiza-se no Rio Grande do Sul, Brasil. A Barra do Rio Tramandaí desemboca junto ao Oceano Atlântico e divide os municípios de Tramandaí (margem sul) e Imbé (margem norte).

FONTE: Elisa Ilha e Emanuelly Silva.

${ }^{2} \mathrm{O}$ presente artigo resulta da pesquisa realizada para elaboração do Trabalho de Conclusão de Curso em Biologia da primeira autora, num diálogo com os demais pesquisadores no contexto da UFRGS, Campus Litoral Norte. Portanto, trata-se de um estudo da área de Biologia/ Ecologia que se aproxima do campo antropológico. 
2. Os pontos de vista: a pesca cooperativa na

\section{"Barra"}

A pesca é uma das mais antigas artes de caça desenvolvidas pelos coletivos humanos (Pereira, 2002). Atividade intimamente relacionada aos processos naturais, que vincula fatores geomorfológicos, oceanográficos, ecológicos e históricos à ocupação da costa brasileira e o consequente extrativismo relacionado a cada região. O relevo, por exemplo, determina planícies e baías, favorece o surgimento de nichos ecológicos locais e a exploração de apetrechos de pesca adequados à disponibilidade de biomassa local. As categorias de pesca, como um todo, podem ser encontradas junto aos periódicos da $\mathrm{FAO}^{3}$, no entanto, o presente estudo volta-se à prática que apresenta formato regional-específico de utilização de recursos, uma prática sui generis de pescaria de subsistência com forte caráter artesanal (Cardoso, 2003). Trata-se do que aponta Diegues (1983): "as modalidades de relações sociais entre os agentes da produção parecem ser influenciadas pelas condições naturais em que se realiza essa atividade".

Os grupos de pescadores artesanais característicos do Litoral Norte Gaúcho são legatários de diversas e distintas técnicas pesqueiras, como são a pesca de tarrafa, a pesca cooperativa com os botos, a pesca de bolo, a pesca de aviãozinho, entre outras. Através destas técnicas, os grupos de pescadores manejam de forma sustentável os recursos gerados pela abundância das águas oceânicas, dos rios e das lagoas presentes no território em questão (Medeiros, 2001) $)^{4}$.

Partimos do pressuposto de que a pesca artesanal tem, a partir do esforço de trabalho (individual ou coletivo), a busca de alimento para consumo próprio, familiar e/ou comunitário, o que elucida o importante papel social da atividade (Harayashiki et al., 2011; Lopes, 2014). Tais aspectos diferenciam categoricamente a extração artesanal e em pequenas dimensões dos chamados "recursos naturais" à coleta em larga escala de tais recursos - prática geralmente chamada de pesca "industrial", associada ao uso de grandes embarcações e tecnologias acessíveis a uma classe específica de trabalhadores do mar. Na comunidade da "Barra", a prática artesanal de pesca é costeira, em plataforma rasa, sem o uso de embarcações e com os pescadores envolvidos em constante mobilidade, acompanhando a movimentação tanto dos botos quanto dos cardumes ${ }^{5}$ (Moreno et al., 2009; Santos et al., 2018).

Além do consumo, sabe-se que a venda do produto da pesca é prática comum entre os pescadores artesanais, uma vez que pequenos volumes de pescado são comercializados a preços mais baixos em relação ao pescado vendido em peixarias ou supermercados, associados ao acesso fácil do consumidor a mercadorias frescas. $\mathrm{O}$ contato direto dos compradores com os pescadores torna essa prática de comércio local sustentável e relativamente atrativa aos consumidores (Medeiros, 2001). De outro lado, os pescadores têm relatado que, embora

${ }^{3}$ Food and Agriculture Organization of the United Nations.

${ }^{4}$ A diversidade de saberes e técnicas de manejo quanto aos elementos da natureza proporcionados pela abundância e diversidade ambiental também pode ser verificada entre os agricultores familiares enraizados na microrregião.

${ }^{5}$ Sobre o contexto da pesca artesanal praticado na Barra sugerimos Abraão Martins Terceiro (2017), além de Dannieli Firme Herbst \& Natalia Hanazaki (2014). 
considerem sua prática importante, demandando reconhecimento e valorização por parte do conjunto da sociedade, vislumbram com pessimismo as possibilidades de perpetuação desta prática ao longo do tempo, ao menos como forma exclusiva ou prioritária de sustento, seja pela degradação ambiental, que coloca a pesca artesanal em risco, ou ainda devido ao baixo rendimento econômico obtido com a atividade no contemporâneo. Vários interlocutores afirmam que não querem que seus filhos sejam pescadores.

No sul do Brasil, duas regiões apresentam peculiaridades quanto ao formato de pesca envolvendo a interação entre coletivos humanos e de cetáceos junto ao oceano Atlântico. As relações compostas pelos golfinhos-de-Lahille (Tursiops gephyreus; Odontoceti: Delphinidae) e pescadores artesanais de tarrafa pautam a chamada pesca cooperativa. (Simões-Lopes et al., 1998; Ilha et al., 2018). Trata-se de uma pesca ritualizada e tradicional que consagra a Barra do Rio Tramandaí como uma das localidades mundiais onde sistematicamente a prática acontece. No município de Laguna, em Santa Catarina, ocorre um formato semelhante de pesca, porém, cada estuário apresenta singularidades em relação às técnicas de pesca e relações próprias entre os sujeitos humanos e não humanos que compõem a atividade interespécies (Tabajara, 1992; Simões-Lopes et al., 1998; Peterson et al., 2008; Giacomo, 2014; Catão \& Barbosa, 2018; Ilha et al., 2018).

Os botos - como são popularmente conhecidos pela comunidade litorânea do Rio Grande do Sul - adentram o canal da Barra e perseguem os cardumes de tainhas (Mugil liza), encurralando-os junto aos pescadores (Simões-Lopes, 1991; Ilha et al., 2018). A partir da percepção dos movimentos realizados pelos botos no canal, os pescadores se aproximam dos cetáceos e iniciam as atividades de pesca (Simões-Lopes, 1991; Santos et al., 2018). O boto que pesca cooperativamente exerce um movimento característico com a cabeça, que sinaliza o momento apropriado para a jogada da rede na água, signo esse que é interpretado pelo pescador, atento às movimentações do animal. Assim, ao lançar sua tarrafa a partir da sinalização do boto, o pescador apreende o cardume de tainhas (Tabajara, 1992; Simões-Lopes et al. 1998; Ilha, 2016).

Com a batida da rede na água, as tainhas se desorientam do cardume, dispersando-se, o que possibilita ao mamífero marinho alimentar-se dos peixes aleatoriamente (Simões-Lopes, 1991). Logo, aliar-se ao pescador torna mais fácil a captura das presas pelos botos. Para o pescador, a localização espacial do cardume de tainhas é revelada pelo boto, bem como o momento ideal de lançar a tarrafa na água, otimizando a eficácia da pesca e a energia despendida por ambos (Simões Lopes, 1991; Santos et al. 2018).

A partir do quadro proposto, vislumbramos a pesca cooperativa enquanto um fenômeno que singulariza as relações estabelecidas entre humanos e cetáceos quando experiências interculturais atravessam gerações (Marques, 2017) e culminam em interações capazes de beneficiar ambas as espécies envolvidas na atividade de pesca. Trata-se, assim, de uma parceria eficiente de pesca da tainha. Além disso, as sociabilidades, territorialidades e memórias dos pescadores artesanais, reconhecidos como comunidades tradicionais (Diegues, 2000; Marques, 2017) que praticam tais lugares há muitas gerações, indicam o quão ricas são as relações cooperativas em jogo naquele ambiente estuarino e a relevância desta prática ímpar no extremo sul do Brasil. 


\section{A parte: pescadores e botos no estuário}

Os golfinhos manifestam vasta capacidade cognitiva e de aprendizagem social (Rendell \& Whitehead, 2001). Estes animais são comumente vistos desempenhando comportamentos variados, traçando estratégias de forrageio específicas nos estuários que usualmente praticam e difundindo suas experiências sociais através da observação dos membros do grupo. É justo nos primeiros anos de vida que essa via de repasse geracional é protagonizada, principalmente, pela transmissão materna. A aquisição de tais habilidades pode auxiliar os golfinhos a desenvolver agilidade motora, promover o reconhecimento parental e flexibilizar a gama de comportamentos executáveis (Simões- Lopes et al., 1998; Mann \& Sargeant, 2003; Sargeant et al., 2005; Spinelli et al., 2008; Serpa, 2019) que se efetivam nas complexas relações entre mãe e prole, e destes para com o ambiente, demais membros do grupo de botos e espécies relacionadas ao estuário do Tramandaí.

Golfinhos do gênero Tursiops apresentam alta plasticidade comportamental e desenvolvem-se sob fortes interações inter e intraespecíficas, o que os caracteriza como animais sociais (Connor et al., 2000). Formas culturais, comportamentos e interações sociais são esferas intimamente relacionadas à vida social desses animais, uma vez que são agenciamentos de perpetuação das atuações coletivas e consequente produção e reprodução de modos de comportamento ao longo das gerações, trazendo benefícios adaptativos (Laland \& Galef, 2009; Serpa, 2019). Tais aspectos podem fidelizar golfinhos a regiões com boa disponibilidade de presas e forrageio otimizado, associados a espaços seguros para exercer cuidados parentais e ensinar seus filhotes a caçar e desenvolver-se como indivíduos autônomos, mas com significativa vida social intragrupo (Guinet, 1991; Hoelzel, 1991; Rossbach \& Herzing, 1997; Connor et al., 2000). É preciso indicar que, neste trecho específico, abordamos os conceitos Cultura e Transmissão cultural a partir do modo com os autores do campo da Biologia os têm utilizado, mas nuançados pelo campo antropológico.

Embasando-nos na perspectiva de Ingold (2000), entendemos que não se pode separar o domínio das relações humanas das relações com os não humanos na medida em que estas compõem, no mesmo nível, um ambiente comum. De acordo com o autor, as representações gerais quanto à exploração do ambiente, à domesticação ou o "uso" dos animais pelos humanos estão inseridas numa ampla narrativa evolucionista acerca do processo de emancipação humana, marcada por um suposto domínio da natureza. Tais representações apontam para o modo profundo como concebemos a ideia de natureza, por um lado, e nossa própria animalidade, de outro (Ingold, 2000). Longe desta concepção de uma interação meramente exploratória entre pescadores e botos - no sentido de vantagens mútuas na captura da presa, a cultura apropriando-se da natureza através da técnica - a Barra do Rio Tramandaí sedia uma forma muito mais densa de relação humanimal, que envolve formas sociais de reconhecimentos, afetos e integração que produzem expressões paisageiras ${ }^{6}$ singulares no contexto da Barra do Tramandaí.

${ }^{6}$ A ideia de uma experiência paisageira tem relação direta com o pensamento do sociólogo francês Pierre Sansot (1983), do geógrafo francês 
No estuário do Rio Tramandaí, uma população residente de botos utiliza a área para descansar, ensinar sua prole a forragear e estabelecer cooperação com os pescadores artesanais na busca conjunta pelos cardumes de peixes. Os botos podem ser considerados fidelizados ao estuário (Santos, 2016; Giacomo \& Ott, 2017), pois são rotineiramente vistos em suas águas, e sua presença é evidenciada na localidade há pelo menos sessenta anos, período equivalente ao histórico dos relatos de cooperação entre botos e pescadores na região. É digno de nota que os golfinhos entram espontaneamente no estuário da Barra (Tabajara, 1992).

Em estudo recente, Wickert et al. (2016) reconheceram através de dados morfológicos, duas linhagens de cetáceos do gênero Tursiops ocorrendo no Atlântico Sul Ocidental: uma categorizada como Tursiops truncatus e, outra, revalidada através de seu estudo, Tursiops gephyreus Lahille, 1908. Os botos da Barra fazem parte do segundo táxon, reconhecido por habitar as águas costeiras do Sul do Brasil, do Uruguai e da Argentina (Wickert et al, 2016). O boto-de-Lahille foi recentemente incluído na Lista Vermelha de espécies ameaçadas de extinção da IUCN ${ }^{7}$ (The IUCN Red List of Threatened Species ${ }^{\mathrm{TM}}$ ), na categoria vulnerável (VU) (Vermeueln et al., 2019).

O convívio cotidiano entre botos e pescadores faz com que estes últimos reconheçam os cetáceos fidelizados ao estuário e praticantes da pesca coo- perativa com humanos ${ }^{8}$. Neste sentido, os pescadores artesanais de tarrafa narram como se dão as relações boto-pescador presentes na Barra do Rio Tramandaí, a partir da leitura que estabelecem das paisagens estuarinas que praticam conjuntamente com os cetáceos ao longo de décadas.

Os trabalhadores do mar presentes no nosso estudo vivem no Litoral Norte do estado e estabelecem essa parceria de caça com os botos como uma forma de obtenção de alimentos, além de seu sustento próprio e de suas famílias, pois os peixes que não são consumidos são vendidos. Além disso, a pesca também gera renda a esses trabalhadores quando os apetrechos de pesca - tarrafas e outros instrumentos, produzidos ou consertados por eles, tornam-se um meio de obtenção de um ganho a mais na economia da pesca. Sendo assim, a pesca cooperativa é de grande importância histórica, econômica e sociocultural na região (Zappes et al., 2011; Santos, 2016; Camargo et al., 2016).

De acordo com dados do CEPSUL $^{9}$ (2007), mais de nove mil famílias dependem da pesca artesanal na planície costeira do Rio Grande do Sul. Sabe-se que o formato de pescaria com os botos corre sérios riscos quanto à sua possibilidade de perpetuação no futuro, diante dos dilemas socioambientais que atingem e/ou ameaçam a região, uma vez que os botos figuram como espécies ameaçadas de extinção, e os pescadores artesanais são uma categoria desvalorizada na sociedade contemporânea.

Augustin Berque (2009), bem como com as reflexões de Cornelia Eckert (2009). Operamos com o termo neste estudo mais livremente, buscando indicar as "formas sensíveis" pelas quais experienciamos os lugares ao longo do tempo, a partir dos sentidos, de determinados pontos de vista, bem como de noções de natureza.

${ }^{7}$ União Internacional para Conservação da Natureza.

${ }^{8}$ Não seria exagero dizer que o reconhecimento recíproco é uma realidade, já que os cetáceos pescam diariamente com os pescadores ao longo dos anos que duram as associações, em alguns casos há mais de 30 anos.

${ }^{9}$ Centro de Pesquisa e Conservação da Biodiversidade Marinha do Sudeste e Sul. 
Além disso, o colapso ambiental assola os organismos aquáticos e diminui drasticamente os volumes disponíveis de pescado (Ilha, 2016; Santos et al., 2018). A ausência de políticas públicas que olhem por esses trabalhadores e entendam suas demandas também negligenciam a realidade do grupo social, especialmente quando se pensa em pescadores profissionais - legalizados, portanto.

\section{Acerca do campo na Barra: diálogo entre Biologia e Antropologia}

A pesquisa de campo foi grandemente favorecida pela relação consolidada entre os pesquisadores e extensionistas ligados ao Projeto Botos da Barra e os pescadores artesanais, membros da comunidade que cooperam na pesca com os botos. A familiaridade estabelecida há mais de vinte anos entre os pescadores de tarrafa e o grupo de pesquisa ${ }^{10}$ contribuiu para o estreitamento de laços de confiança entre os pesquisadores e permitiu a abertura de portas para iniciar-se o estudo em questão. Neste sentido, através da busca por um entendimento ampliado das formas com que a sociobiodiversidade constitui e dialoga com as paisagens locais, a presente investigação priorizou a análise qualitativa para suas reflexões. Enquanto algumas correntes cientificistas buscam a imparcialidade e a objetividade nos seus resultados, uma pesquisa qualitativa como esta busca contemplar as especificidades presentes nos objetos de estudo (no caso, os coletivos de pescadores da Barra), dando atenção às maneiras como compreendem as paisagens a partir de representações simbólicas, portanto, de fenômenos cujos contornos não podem ser quantitativamente mensurados pelo pesquisador.

Segundo Minayo (2001), o método qualitativo de estudo trabalha com significados, histórias e percepções, através da obtenção de dados descritivos, o que pode corresponder a uma análise mais profunda e integral dos fatos. A pesquisa qualitativa tende a salientar os aspectos dinâmicos da experiência para apreender a totalidade do contexto daqueles que o vivenciam (Cabral, 2000; Polit et al., 2004; Silveira \& Córdova, 2009; Ilha, 2016).

Para a realização de nosso estudo, dispomos de ferramentas específicas de caráter etnográfico, englobando técnicas de produção de dados, como a observação participante, as entrevistas abertas/ semiestruturadas, as conversas informais com e entre os membros do universo investigado e, ainda, a manutenção de uma caderneta de campo onde as informações relevantes eram anotadas (Velho, 1978). Nos propusemos, no presente estudo, a participar do cotidiano vivido na Barra, de forma a observar e interpretar os acontecimentos em torno

\footnotetext{
${ }^{10}$ No âmbito da Barra do Tramandaí reconhecemos que a produtiva aproximação entre o conhecimento técnico-teórico de caráter acadêmico e as experiências culturais de caráter simbólico-práticas, adquiridas através da passagem geracional pelos coletivos humanos tende a beneficiar sistemas biológicos, sociais e econômicos, como é o caso da "Barra". A partir desta perspectiva, o Projeto Botos da Barra, realizado pelo Centro de Estudos Limnológicos e Costeiros do Campus Litoral Norte (Ceclimar/UFRGS Litoral), tem desenvolvido um trabalho de aproximação e troca com os pescadores artesanais, com o intuito de percorrer o caminho da valorização dos profissionais do setor primário, na busca por entender, difundir e valorizar a prática singular da pesca cooperativa em todos os seus aspectos, uma vez que trabalhar e aprender conjuntamente é uma forma de combater desigualdades sociais e valorizar grupos historicamente desconsiderados (Brasil, 2012). Tal perspectiva, obviamente, vem associada aos estudos de ecologia e às atividades voltadas à educação que valorizem a conservação do ambiente estuarino da Barra, com enfoque no coletivo de botos-de-Lahille que se fidelizaram a ele ao longo do tempo.
} 
da pesca cooperativa que nela se desdobravam. Para tanto, consideramos, concomitantemente, aspectos das trajetórias de vida dos pescadores artesanais, quando suas práticas entendidas como suas socializações, individualizam seus olhares sobre as paisagens a partir de uma experiência comum [a pesca cooperativa] junto àquele contexto, revelando as formas de interação com animais não humanos e como se constroem as dinâmicas de pesca a partir delas.

Com o intuito de compreender como se engendram as relações presentes na Barra, para o escopo do presente artigo, enfatizamos saídas de campo semanais realizadas durante três meses ${ }^{11}$ - abril, maio e junho de 2018. Nossas visitas foram conduzidas por conversas informais com os pescadores, sendo as informações resultantes registradas em diário de campo. Primeiramente, tratou-se de observar as práticas da pesca à distância, e de forma discreta, na tentativa de não intervir na movimentação dos seus atores, e como se davam as relações ali presentes.

Buscamos observar/participar de toda e qualquer comunicação entre os profissionais da pesca, ou entre eles e os botos da Barra. Além disso, consideramos as suas conversas formais e informais, frases ditas, manifestações de amizade e tensões, bem como as relações na venda dos peixes e as especificidades dos apetrechos de pesca, como tamanho de malha e técnicas no lançar a tarrafa, por exemplo. Tais aspectos da vida social na Barra indicam o que foi considerado como elementos relevantes à pesquisa e registrado junto à caderneta de campo. Parece-nos que jamais seria possível traçar perguntas a este coletivo de trabalho, sem antes observar e entender as singularidades humanimais que ocorriam naquele espaço social e as afetividades que abarcavam as relações construídas nele.

Após observarmos o cotidiano da comunidade e traçarmos questionamentos pertinentes à realidade estudada, aplicamos um roteiro com perguntas abertas e semiestruturadas para conduzirmos os diálogos com maior fluidez junto aos pescadores. Todos os pescadores com quem conversamos estão vinculados à Colônia de Pescadores Z40, alocada no município de Tramandaí. É importante ressaltar que as entrevistas foram realizadas durante a temporada de pesca da tainha, entre abril e junho de cada ano, época muito aguardada pelos pescadores. Então, munidos de bom senso diante das demandas de labuta dos trabalhadores, adaptamo-nos às suas rotinas e horários. Considerando que as conversas são facilitadas quando propostas em lugares de rememoração (Ilha, 2016), aplicamos nosso roteiro de entrevista tanto na Barra quanto na casa dos pescadores, de acordo com as preferências dos participantes. As entrevistas semiestruturadas foram realizadas com três dos quatro pescadores notoriamente destacados pela sua constância e tempo de pesca com os botos. Todavia, diversos trechos de conversas e informações coletadas ao longo das nossas visitas à Barra compõem o trabalho. Os diálogos foram gravados para posterior transcrição na íntegra de seus conteúdos a partir da devida autorização do uso de fala e imagem.

Durante as conversas e entrevistas não consideramos apenas o dito pelos pescadores, ou o observado em campo. Observamos os silêncios, os códigos e significados atribuídos ao fenômeno

\footnotetext{
${ }^{11}$ Embora nosso estudo se ancore no vasto material coletado pelos membros do projeto ao longo dos anos, bem como das monografias e artigos produzidos pelo grupo.
} 
relacional da pesca cooperativa, ou mais, à Barra do Rio Tramandaí. Em sua dinâmica a Barra apresenta um vasto arcabouço biocultural, produzido num entrecruzamento de apropriações do espaço e pontos de vista, onde os saberes relevantes para manutenção da interação interespecífica são perpetuados através das gerações de golfinhos e pescadores naquele contexto.

Os diálogos com os pescadores buscavam compreender as suas leituras das paisagens, ou ainda, de como é realizada sensivelmente a partir de atributos perceptivos e sensórios muito próprios ao observador que a lê (Cabral, 2000). Nossas investigações tentaram descrever leituras do espaço, das relações simbólicas e ecológicas quanto ao reconhecimento dos botos, dos saberes, das afetividades presentes nas paisagens. As leituras dos pescadores artesanais vão além da linguagem falada ou da imagem percebida pela visão, tratando-se de um saber corporal que, portanto, está incorporado nos seus gestos, já que a nossa percepção está no corpo - nossa abertura para o mundo. Diríamos, embasando-nos na perspectiva da corporeidade (Csordas, 2008), que tais formas culturais estão inculcadas, corporificadas no próprio ser do pescador artesanal que pesca com tarrafa na Barra do Rio Tramandaí. Eles se comunicam com o ambiente através dos seus detalhes, suas percepções próprias das relações naturais, mas também através das percepções coletivas - ensinadas e aprendidas por seus praticantes desde longa data, em conjunto com os botos.

\footnotetext{
${ }^{12}$ Espécies identificadas pelos autores
}

\section{A naturezacultura da barra como dimensão das dinâmicas paisageiras}

Pra mim é a pesca mais linda que pode existir no mundo! (Airton).

Os frequentadores da Barra são variados e, entre eles, podemos destacar os pescadores artesanais, os pescadores amadores, que durante os finais de semana e período de veraneio, ocupam os espaços, alguns compradores de pescado, que muitas vezes são conhecidos e amigos dos pescadores e, em alguns momentos, as companheiras e esposas dos trabalhadores, sendo pouco frequente a sua presença. Além dos visitantes já citados, pesquisadoras e pesquisadores vinculados ao Ceclimar (Centro de Estudos Costeiros, Limnológicos e Marinhos) e ao Campus Litoral Norte também são comumente vistos na Barra, sendo referenciados como o "pessoal do Ceclimar".

Além dos habitantes humanos, distintos coletivos não humanos interagem com o seu entorno, incluindo os praticantes das paisagens. Entre eles, destacamos as diversas espécies ${ }^{12}$ de aves, como o biguá (Nannopterum brasilianus), o talha-mar (Rynchops niger), o savacu (Nycticorax nycticorax), o gaivotão (Larus dominicanus), o piru-piru (Haematopus palliatus) e a garça-branca-pequena (Egretta thula), sendo que esta última estabelece forte relação com os produtos da pesca, pois quando os pescadores evisceram o pescado ainda na Barra, jogam partes dos peixes na água - como suas cabeças e rabos - e as garças alimentam-se dessas 
partes, o que as mantém sempre próximas dos pescadores. Há, ainda, registros de tartarugas marinhas avistadas pelos pescadores na Barra e que, através de sua descrição, e baseados em registros anteriores, acreditamos tratar-se da tartaruga-verde (Chelonia mydas), o que corrobora estudos feitos na região onde a mesma é apontada como área de constante avistamento desses animais (Monteiro, 2004).

A tainha (Mugilidae) é a espécie alvo da pesca na Barra. O peixe em questão desova no mar, sendo que indivíduos juvenis e subadultos locomovem-se para águas costeiras e estuarinas para crescimento, alimentação e proteção, caracterizando-se como uma espécie catádroma (Vieira \& Scalabrin, 1991; Tabajara, 1992; Lemos et al., 2014). Tainhas formam extensos cardumes e estão entre as espécies de principal relevância econômica no Rio Grande do Sul, além de histórica e cultural para os pescadores artesanais do estado (Vieira, 1985; Lopes, 2014). Esses animais são comumente pescados em todo o Sul do Brasil, e sua pesca é diretamente influenciada por condições ambientais, sendo temperatura e salinidade as mais relevantes (Vieira et al., 2010). Segundo Gilson (45 anos), que é pescador artesanal - uma das pessoas que pescam com os botos desde meados da década de 1980 - e vendedor de peixes nos fins de semana na Barra: "a tainha tem época para aparecer. Abril e maio. Ejunho. Mas assim, ó, abril e até quinze de maio, por ai" (pedimos ao leitor que note a precisão do relato). Ou ainda, como aponta Alzemiro (47), também pescador e morador de Tramandaí:

É que assim, ó, essas tainha tão vindo aqui agora porque foi traineira que cercou [contando sobre uma leva de tainhas grandes, com cerca de $3 \mathrm{~kg}$, que apareceram em grande quantidade na Barra ao longo de junho]. O que é que acontece? O cerco é uma rede.
É rede de anilha, é anilhado. É umas argola, eles botam um cabo por dentro e cercam. Que acontece? Eles puxam, alguma vai escapar entendeu! Às vezes estoura a rede. Ai esse peixe que vem pra costa, essa grandona, graudona, é peixe que escapa deles. Dai ela já vem pra praia, ela vem pra costa, porque é peixe cansado!

Maurino (53), pescador que há mais de quarenta anos pesca com os botos e narra muitas histórias, pois detém vasta bagagem de conhecimentos sobre os botos e a Barra, aponta características distintivas entre os espécimes de tainha: "a tainha quando tem o lombo preto, geralmente é tainha de lagoa. Vindo de lagoa. As do mar são mais claras, tem o lombo claro". Além da tainha, outras espécies de peixe são comentadas pelos pescadores como sendo pescadas na Barra com certa frequência, como robalo (Centropomus sp.), linguado (Paralichthys orbignyanus) e a savelha (Brevoortia pectinata).

\section{1. "Eu nasci nas dunas"}

A dinâmica que produz a união dos elementos que constituem as paisagens da Barra do Rio Tramandaí é desenhada a partir dos olhares dos pescadores artesanais de tarrafa que praticam o lugar. Todos eles pescam há mais de 30 anos na Barra e nos contam que, em média, aos dez anos estavam com suas tarrafas já em mãos, tarrafeando no canal e "correndo com os botos". Alzemiro, por exemplo, relata: "eu saía do colégio, largava minha pasta e vinha pro rio tarrafear. Vinha de tênis e tudo pra pescar. Eu aprendi sozinho!" Entender como esses trabalhadores se relacionam com a natureza estuarina-lagunar e marinha; como interagem com ela e o que levam dessa interação como resultado de 
seu ofício, o que ela lhes ensina e o que eles deixam como ensinamento à ela é a primeira premissa que observamos e podemos relatar aqui: existe uma troca constante de saberes na Barra do Rio Tramandaí, pois como defende Cabral (2000), o sujeito que observa encontra-se envolvido pelo espaço que é apreciado - e praticado - a partir dele mesmo.

O ethos - conjunto de valores e preceitos ético-morais compartilhados (Geertz, 2008) de ser pescador configura formas de saber jogar a tarrafa ao mesmo tempo em que precisa entender a configuração ideal do corpo para uma boa tarrafada: "tarrafear é afrouxar a cintura assim, né!", e perceber qual o vento ideal para pesca, como aponta Maurino:

Uma semanada de nordestão é ruim. É bom sempre ter que entrar um vento, sabe? Dá um minuano, pode ficar uma semana/dez dias. Depois tem que entrar o nordestinho, ó, um ventinho de fora pra clarear a água. Que o leste clarea as águas, né? Fica mais três/ quatro dias de leste, clarinho. Depois outro ventinho, sabe? É bom sempre fazer essa variação. Que nem agora, agora vai começar a dar minuano, tu vai dizer assim: bah que friagem! Por quê? Só minuano. Vem da Argentina aqueles Minuano, né? E frente fria, $e$ frente fria, e frente fria.

Os pescadores da Barra expressam suas percepções sobre as paisagens quando inferem que se a água do canal esfriar demais, só aparecerá "pinguela" - tainha magra e pequena, segundo eles - "parece carne de aipim, parece não, a gente limpa a tainha, ela fica molenga". Portanto, reconhecer a natureza para esses trabalhadores requer observá-la para interagir a partir desse olhar interessado, traçando padrões entre os espécimes pescados, relacionando sua morfologia (corpo "molengo") a determinadas épocas do ano, aos ventos, à tempe- ratura do ambiente e ao quanto isso determina dias bons ou ruins para a pescaria.

Neste sentido, ser pescador significa estar inserido em um espaço relacional, onde o saber-fazer é recebido e transmitido intergeracionalmente através das suas vivências no e com o ambiente, suas práticas cotidianas e suas observações no dia a dia. Mais do que isso, implica uma noção de ética muito presente, pois o respeito visto entre os trabalhadores se mostra, por exemplo, nas falas de Maurino, que contando sobre uma tarrafa que fez artesanalmente para outro pescador, diz: "o mesmo serviço que eu fiz pro cara é o mesmo serviço que eu faço pra mim". Ou ainda, quando Gilson aponta como se dava o processo de iniciação na pesca com os botos quando ele ainda era criança:

Cara, a gente na época não podia pescar junto com os profissionais, com menos de dezoito anos. Então eles davam a carteirinha, assim, de dependente. Meu pai no tempo tinha carteira, então ele se aposentou por isso e tal. Não, minto, o meu pai é aposentado por invalidez. Mas ele sempre foi filiado à colônia de pescadores, ai ele me botou como dependente. E tinha uns fiscais ali, tipo o Presalino, tipo o seu Lino, o falecido Bem-te-vi, que esse era duro mesmo, ele corria com nós, porque nós não podia tarrafear junto. Então a gente roubava uma tarrafinha do pai de vez em quando né, e saía correndo atrás do boto. Da baliza pra trás era um deus nos acuda, quem podia mais jogava menos.

\section{Sobre as mudanças na dinâmica de pesca}

Ao longo das conversas desenvolvidas com os pescadores, algumas questões quanto às novas dinâmicas de pesca surgiram. Segundo os inter- 
locutores, o aumento do número de pescadores frequentemente pescando na Barra (muitos dos quais exercendo a atividade de forma ilegal por não possuírem documentação), além de um acréscimo no número de "filhotes criados" dos botos, é um fato que merece atenção.

É que antigamente quando o boto mostrava, ele [o pescador] esperava né, até ele [o boto] firmar a batida. Hoje esses botinhos acham uma tainha, ou acham dez, ou vinte que seja, um cardume né? O peixe às vezes nem chegou neles e eles já tão pulando 30/40 metros atrás do peixe, do cardume, né. Dá um pulão dai tu bota e, ó, tá 30/40 metros lá na frente.

Os pescadores explicam que a ação de "firmar a batida" remete ao cerco do cardume feito pelo boto. Segundo eles, quando o boto encontra o cardume de peixes, ele bate com sua cabeça uma vez. Inicia o cerco do cardume, encurralando as tainhas cada vez mais próximas à margem do Canal da Barra, já que os pescadores artesanais estão dispostos ao longo dela, sem nenhuma embarcação e, portanto, precisam acessar essas tainhas em uma profundidade razoável. Com o cerco iniciado, o boto realiza a segunda cabeçada. Quando o boto, de fato, cerca o cardume e encurrala as tainhas na posição ideal para a lançada da tarrafa, ele bate sua cabeça uma terceira vez e, segundo pescadores experientes, essa é a hora correta de jogar a tarrafa.

Nota-se que essas especificidades narradas não configuram um padrão de ocorrência, pois o número de batidas de cabeça do animal pode ser superior ou inferior a três. Mas este sistema, de ele "dar a cabeçada" mais de uma vez, é algo de fato atestado por todos os interlocutores que entrevistamos como o "jeito de pescar com o boto", esperando que ele firme a batida e, assim, o pescador dê "tarrafadas de trinta, quarenta, tainhas", segundo relatos. Todavia, a espera pela firmada da batida do boto não é prática comum entre todos os pescadores.

Os estudos de Serpa (2019) encontraram dezesseis padrões de comportamento de forrageio dos Botos da Barra, variando entre "cabeçadas", batidas de nadadeira caudal ou outros, sendo todos vinculados ao momento em que é jogada a tarrafa. A autora, porém, atestou que somente em quatro dos dezesseis comportamentos desempenhados os pescadores de fato pegam peixes em suas redes. Observamos, e nos foi relatado, que pescadores intimamente relacionados à pesca cooperativa leem essa peculiaridade da relação com mais atenção, esperando a batida firmar e o momento ideal de lançar suas tarrafas. Em contrapartida, pescadores menos experientes, ou principalmente aqueles que não são pescadores e desconhecem o ritual, jogam suas tarrafas "em qualquer respirada que o boto dá". Segundo relata Maurino:

Antes, esses botos grandes né, quando o boto mostrava nós esperava, ele dava uma mostrada, dava duas e nós ficava esperando o tempo do boto, né? Pô, ele tá mostrando, a tainha tá aqui, do meio dele pra frente. Entendeu? Pra botar uma pra matar, né? Hoje o boto mostra e tu já tem que botar, né? Se tu não botar o outro [sujeito] bota. Dai tu já bota sempre enforcado, né? Ah, mas of fulano ali é ruim... mas cada vez que o boto mostra pra ti já tem dois, três do teu lado, né? Te apertando. Daí, se tu não botar, deu... dai tu bota!

Como a relação cooperativa entre botos e pescadores caracteriza um saber coletivo, aprendido e ensinado entre todos os presentes na relação, se um dos atores não aprender a pescar em parceria, fica evidente que a própria parceria estará em risco. Os 
pescadores explicam que quando as fêmeas entram no canal da Barra com seus filhotes, ensinando-os a pescar, elas dão suas "cabeçadas" mostrando aos filhotes como mimetizar o comportamento. Quando seus filhotes realizam o movimento de cabeça, os pescadores "amigos dos botos ${ }^{13}$ " lançam suas tarrafas no espaço que está sendo demarcado pelo filhote de boto - mesmo sabendo que não há cardumes ali - para que o filhote entenda que ao bater sua cabeça o pescador jogará sua tarrafa em consequência, em um movimento uníssono. Ou seja, é um aprendizado conjunto, pois o filhote está descobrindo como cooperar com o pescador e beneficiar-se dessa cooperação, adquirindo algumas tainhas do cardume apreendido. Além disso, o pescador está incentivando o boto a manter viva a parceria, ensinando e aprendendo a pescar com o filhote - trata-se, nestes termos, de um comportamento mimético produzido e reproduzido na interação interespécies.

Quando os pescadores defendem que é preciso esperar "o boto firmar a batida", eles estão intrinsecamente defendendo que os botos aprendam e desenvolvam um melhor cerco dos cardumes de peixes, pois é aí que o nível de precisão da pesca é traçado e os envolvidos são beneficiados. Sendo assim, estimular pescadores recentemente vinculados à pesca cooperativa a entender a importância desses processos de aprendizagem, quando os botos precisam ser também estimulados a dar suas cabeçadas em momentos de favorável cerco aos cardumes, é uma das frentes de essencial perpetuação para preservação da pesca cooperativa no contexto sul-riograndense. Além disso, é importante dialo- gar com aqueles sujeitos não pescadores (e.g., sem licença de pesca) que estão ali disputando o espaço com os pescadores artesanais e, em muitos casos, como estes últimos nos dizem recorrentemente, atrapalhando a pesca com o boto.

Tais experiências são portadoras de significações que repercutem nas visões de cada pescador sobre as paisagens que ele pratica na barra e sobre as afetividades que esse território desperta e alimenta, pois o afeto presente na relação boto-pescador se renova com o nascimento de novos filhotes, e é evidenciado quando algum boto vem a falecer. Abaixo, apresentamos a imagem de Airton, pescador artesanal de referência na pesca cooperativa, um exímio conhecedor dos botos, que desempenhou sua trajetória de vida sempre pescando com esses animais e inclusive atuou, em muitos momentos, como difusor da prática, auxiliando o Projeto Botos da Barra com seus conhecimentos e experiências junto aos botos. Airton faleceu em 2019, pouco antes de nos conceder seus relatos. Apresentamos a imagem mostrando o pescador ao lado do boto Lobisomem, quando o senhor levou seu filho para despedir-se do animal que foi encontrado morto na praia em 2005. Talvez com uma imagem, o grau de afetividade estabelecido entre pescador e boto, humano e não humano, possa ser compreendido. Faz-se importante ressaltar o fator afetivo da relação cooperativa protagonizada por estes atores sociais, pois a afetividade em questão está também intimamente relacionada às maneiras como esses pescadores se relacionam sensivelmente com as paisagens, como leem suas dinâmicas e as vivem

\footnotetext{
${ }^{13}$ Categoria engendrada pelo Projeto Botos da Barra na interlocução com os pescadores para inscrever e, consequentemente, estreitar relações com os trabalhadores que historicamente pescam com os botos, na tentativa de promover visibilidade, além de envolvê-los mais efetivamente no processo de conservação dos cetáceos e do ecossistema da barra como um todo.
} 
no seu cotidiano de labuta, o que no nosso ponto de vista tem enorme significado para a conservação de uma espécie marinha no seu ecossistema, ambos em risco diante de determinados projetos de desenvolvimento $^{14}$.

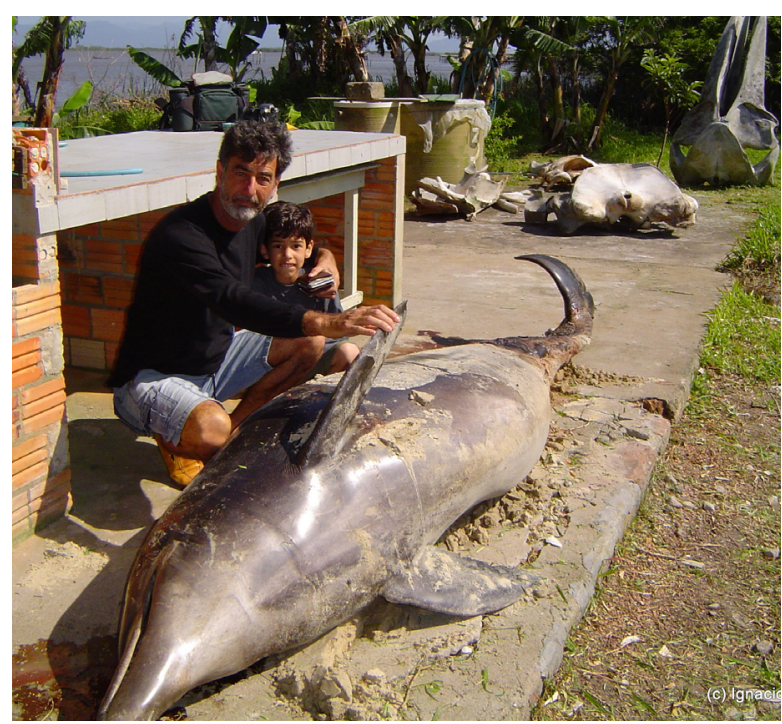

FIGURA 2 - pescador Airton (in memoriam) e seu filho despedindo-se do boto Lobisomem.

FONTE: Ignacio Benites Moreno (Ceclimar/ UFRGS).

\section{Conhecimentos tradicionais na Barra}

Pescador pra tu saber que é pescador, ter certeza que é pescador, tu chega na casa dele e abre a estante, o que é que tem, né? Que nem aqui né, aqui embaixo aqui né, minhas garrafa térmica de praia, corda, o pano que eu boto aqui no piso pra trabalhar no remendo né, é sacola de linha de tarrafa, ó, é assim, né? Casa de pescador, pode ver linha ali, tarrafa! (Maurino)

Cada pescador reconhece os botos da Barra estabelecendo uma leitura particular sobre eles e as dinâmicas das paisagens exercidas entre eles, a partir de um conjunto próprio e específico de atributos relevantes ao seu olhar, que se diferenciam dos que seriam significativos ao olhar do outro, mas que se aproximam quando todos os pescadores reconhecem os mesmos botos que atuam na pesca cooperativa. Independentemente dos caracteres relevados por eles no reconhecimento, todos sabem que Coquinho está entrando no Canal da Barra mediante certas percepções da "personalidade" do golfinho ${ }^{15}$. São saberes que emergem da partilha de aprendizados, pois se constroem de forma cole-

\footnotetext{
${ }^{14}$ Além da urbanização desordenada, um estudo técnico para a construção de um novo empreendimento rodoviário no litoral norte do Rio Grande do Sul, chamado “Avenida Litoral”, foi realizado pela Secretaria Estadual de Habitação e Desenvolvimento Urbano do Rio Grande do Sul, por intermédio da Fundação Estadual de Planejamento Metropolitano e Regional. O projeto foi configurado para conectar em uma única rodovia os municípios da região. O estudo técnico propõe quatro traçados de alternativas para o congestionamento da ponte Giuseppe Garibaldi sob o estuário do Rio Tramandaí. Porém, esses mesmos traçados são porções do território definidas como áreas prioritárias para conservação da biodiversidade brasileira, segundo o Ministério do Meio Ambiente. Diversas espécies sensíveis às mudanças de habitat ocorrem na região, inclusive com grau de ameaça de extinção regional, nacional ou global. Visto que, o crescimento desordenado da urbanização, junto à descaracterização dos ambientes naturais às margens do estuário do Rio Tramandaí, são apontados como os principais impactos para estas espécies, uma nova construção rodoviária dificultaria grandiosamente a conservação da biodiversidade local, incluindo a pesca cooperativa (Camargo, 2019).

${ }^{15}$ As personalidades dos golfinhos que utilizam o estuário, seus momentos de brincadeira, bem como os de "trabalho" são observados pelos pescadores, o que expressa significativa sensibilidade na leitura das paisagens que praticam conjuntamente com os cetáceos e os demais elementos que as constituem e dinamizam - o que entendemos como uma forma de evidenciar a riqueza do hábito e do empirismo na observação e prática mesma do contexto socioambiental em questão.
} 
tiva, quando na impossibilidade de se traçar uma linha morfológica ou comportamental para narrar o reconhecimento individual, ele se mostra nas diferenças que unificam os olhares desses pescadores artesanais sobre os botos.

É através da ideia acima que entendemos "conhecimento tradicional", uma vez que ele não se faz somente a partir de repasse cultural entre gerações. Ele é pautado por aprendizados prévios, obviamente, mas ele também se constrói sobre bases muito individuais de cada pescador artesanal (percepções acuradas, válidas e reconhecidas, mas diferentes), sendo aprendidos por eles nas suas práticas cotidianas na Barra, já que aprendem praticando (Ingold, 2000).

As relações entre pescadores e botos que se desenrolam da Barra do Rio Tramandaí, como apontamos anteriormente, vão além de vantagens mútuas na captura da tainha. Trata-se de uma forma de interação afetiva, contínua, comunicacional: os botos percebem o ambiente, cercam o cardume, apontam, mostram, dão sinais sobre a localização das presas; estes sinais são bem ou mal respondidos pelos pescadores, como nos informam os nossos interlocutores, de acordo com sua habilidade de compreendê-los. Ou seja, os botos têm agência não apenas sobre a tainha (presa), mas também sobre os pescadores (parceiros de predação). Os pescadores aprendem com os outros - pescadores e botos, humanos e não humanos - a perceber as coisas, e esse aprendizado fornece chaves para a construção de sentidos (Ingold, 2000) sobre o ambiente. A partir do saber perceber tais sinais, entram em jogo as técnicas de manejo dos instrumentos de pescaaqui, sobretudo, a tarrafa como artefato que propicia a captura do peixe. Aprende-se a lançar a tarrafa, dizem-nos os nossos interlocutores, com os mais velhos, olhando atentamente outros pescadores mais experientes; mas, sobretudo, aprende-se fazendo, praticando. Tais práticas, ensina-nos Ingold (2000), são produzidas no engajamento de sujeitos e suas perícias (skills) na materialidade que os circunda, emergindo em contextos relacionais de envolvimento mútuo entre populações e ambientes.

O conhecimento dito tradicional está em constante modelagem e remodelagem, é dinâmico. Como aponta Dooren (2016) quando defende que os diferentes modos de imersão atentiva dão existência a distintos mundos, as individualidades dos pescadores artesanais da Barra constroem a unidade dinâmica e coletiva de que eles fazem parte. Saberes outros, unificados por um mesmo espaço social habitado com os não humanos.

Esse cenário de interações faz da Barra um espaço relacional que instaura processos de ajuda mútua, no sentido de que há uma ressonância de aprendizados e ensinamentos entre o ambiente e quem nele se insere. Quando Maurino propõe que "esse filhote aí, da Geraldona, ainda tá pequeno, mas dezembro, final do ano ali, ele já tá trabalhando", reconhecemos um senso de coletividade, de relação de trabalho, da relação de sustento presentes na Barra. Percebemos a afetividade intrínseca à declaração quando há o senso de confiança, de que a parceria se manterá e em um fluxo constante de aprendizagem mútua, eles trabalharão juntos. As interações estabelecidas entre humanos e cetáceos configuram uma relação de trabalho. É impressionante como, com a chegada de um boto no Canal da Barra, a atmosfera do lugar é alterada, tomada de tensão e espera, de observação e elaboração de estratégias de lanço da tarrafa para, enfim, culminar na captura conjunta dos peixes. Se todos os pescadores estão sentados fora d'água, em minutos eles 
abraçam suas tarrafas e dispõem-se na beirada do canal, iniciando a atividade de pesca.

As regiões costeiras da Mauritânia - África; do Myanmar e da Índia -Ásia; da Austrália - Oceania, além da costa das Américas, são exemplos de regiões onde a interação de forrageio entre humanos e não humanos acontece e é particularmente protagonizadas por pescadores e golfinhos. (Simões-Lopes, 1991; Smith et al., 2009; Kumar et al., 2012). Porém, poucos são os locais em que ocorre uma relação semelhante, onde humanos dão nomes a animais silvestres e interagem com eles cotidianamente referindo-se aos golfinhos através dessas nomeações, sequer encontramos alguma sinonímia à pesca que acontece em Tramandaí e em Laguna ${ }^{16}$. Pode ser que Maurino, ao ver Geraldona, por exemplo, observe características morfológicas da sua nadadeira dorsal, a forma com que ela bate sua nadadeira caudal na água e, quem sabe, como ela faz o seu cerco do cardume, enquanto Alzemiro observe a natação e a forma de comunicação dela com sua prole, porém, ambos sabem que é a Geraldona, ou seja, mesmo com caracteres distintos de diagnóstico, o mesmo boto é individualizado, pois os conhecimentos dos pescadores se unificam quando o convívio diário com esses animais é o que dá o tom da relação, é o que os faz se reconhecerem mutuamente. A Pesca Cooperativa é composta de habilidades complementares, de conteúdos e subs- tâncias que, somadas, constroem as relações presentes nas paisagens que aqui buscamos descrever. Advindo de tal singularidade, o Projeto de Lei 0112/2017 considera Patrimônio Cultural de natureza imaterial a pesca profissional artesanal no município de Tramandaí. Em 31 de janeiro de 1990, os Botos (Golfinhos) da espécie Tursiops Truncatus (- gephyreus) existentes na Barra do Rio Tramandaí foram declarados como Patrimônios Naturais do Município de Imbé (Decreto 49 de 31 jan. 1990). Além disso, segundo a Lista Vermelha de espécies ameaçadas do Rio Grande do $\mathrm{Sul}^{17}$, formulada em 2014 a partir dos critérios de ameaça propostos pela IUCN, a forma costeira do golfinho-nariz-de-garra (- Tursiops gephyreus) foi avaliada como vulnerá$v e l$, devido à alta fragmentação de habitat unido ao crescente grau de antropização das regiões costeiras do estado (Wickert et al., 2016). Além disso, como citado anteriormente, o Boto-de-Lahille encontra-se atualmente ameaçado de extinção em nível mundial (Vermeulen et al., 2019).

\section{Considerações finais}

Apresentamos, no presente artigo, elementos que denotam a complexidade envolvida na prática da pesca cooperativa entre pescadores artesanais e botos na captura da tainha. Os pescadores da Barra do Rio Tramandaí leem esta paisagem, em suas

\footnotetext{
${ }^{16}$ Os pescadores artesanais da Barra do Rio Tramandaí dispõem de um alto nível de acuracidade no que se refere às relações com os botos, o que se evidencia quando observados e questionados sobre os botos da Barra (Ilha, 2016). Os botos são particularmente nomeados por esses trabalhadores da pesca. Segundo busca bibliográfica tal prática - nomear individualmente animais silvestres, nunca foi registrada em outras localidades além de Tramandaí e Laguna - o que indica imensa individuação desses animais (Catão \& Barbosa, 2018). A tradição na manutenção de uso desses nomes ao longo dos anos está atrelada ao fato de os profissionais da pesca reconhecerem os botos individualmente. A partir de sua entrada no canal da Barra, os pescadores são capazes de inferir/identificar qual golfinho está chegando ao local, se é Geraldona, Coquinho, Rubinha, ou outros dos oito animais fidelizados ao estuário (Santos, 2016).
}

${ }^{17}$ Rio Grande do Sul, Decreto Estadual n. ${ }^{\circ}$ 51.797, de 8 de setembro de 2014. 
dinâmicas - os ciclos das marés, a direção e intensidade dos ventos, a turbidez da água, as variações de temperatura, etc. A partir desta leitura, buscam reconhecer as melhores possibilidades de sucesso em sua prática, através de técnicas desenvolvidas com base em sua percepção ambiental muito sutil no que tange às condições ideais à pesca. Este sucesso passa sempre pela presença dos botos, que os pescadores devem conhecer e compreender, afinal, devem saber ler seus sinais - ou seja, comunicam-se com eles na pesca. Além disso, reconhecem os botos em sua individualidade, a partir da observação de suas características físicas e comportamentais, os nomeiam e conhecem os graus de parentesco entre eles.

Por este motivo, sustentamos nossas considerações a partir das categorias propostas por Collot (1990) quanto à à percepção da paisagem. Argumentamos que a pesca cooperativa deve ser entendida como elemento central no ponto de vista dos pescadores artesanais quanto à percepção desta paisagem, uma vez que o ponto de vista aporta a singularidade da pesca cooperativa, sendo esta uma prática de subsistência e experiência vital abarcada por múltiplos afetos. A parte atua como a possibilidade de conhecer os atores que compõem essa dinâmica - pescadores e botos - para entender o tom dessa interação. E o conjunto enlaça as categorias anteriores, quando, através do conhecimento tradicional, aliado ao conhecimento praticado na individualidade de cada pescador e de cada boto da barra, a pesca, os botos e os pescadores são retratados sob a ótica da construção de identidades. A pesca cooperativa faz com que as vidas destes pescadores sejam intensamente influenciadas pelos botos, tanto é que os pescadores reconhecem e nomeiam os animais. Ou seja, parece-nos que perpetuar a conservação de uma das categorias que citamos (o ponto de vista, a parte e o conjunto) é conservar a prática cooperativa presente na Barra de maneira ampla, pois todas formam uma unicidade dinâmica, evocando convergências de imagens da pesca com o boto, dotadas de vasto aporte histórico, social e ambiental no estuário do Tramandaí.

Nestes termos, para além deste ponto de vista dos pescadores, podemos argumentar agora que a pesca cooperativa entre pescadores artesanais e botos configura uma prática interacional interespecífica que ocupa um papel fundamental na composição da própria singularidade da paisagem estuarino- lagunar da Barra do Rio Tramandaí. A pesquisa qualitativa que embasa este estudo busca traçar, a partir da perspectiva dos pescadores, aspectos das agências humanas e não humanas que constituem as experiências praticadas neste território, reconhecidas como tradicionais e que distendem-se no tempo. Os pescadores, no entanto, veem-se desvalorizados, pouco reconhecidos e ameaçados por uma série de fatores e fenômenos, sobretudo ambientais, que os conduzem a um pessimismo quanto à possibilidade de perpetuação no futuro desta modalidade de pesca que os constitui como sujeitos no mundo. A partir do exposto, fica evidente a necessidade de traçar-se -se estratégias de conservação para os botos da Barra, bem como para a pesca cooperativa enquanto todo complexo, pois, além de fidelizar estes animais ao território que comumente é compartilhado por eles e os pescadores na pesca, é um elemento (sensível e pouco explorado) para que turistas e viajantes conheçam esta interação entre humanos e não humanos no contexto gaúcho. 


\section{Agradecimentos}

Os autores gostariam de agradecer a todos os pescadores artesanais que vivem e sobrevivem da pesca cooperativa no Litoral Norte do Rio Grande do Sul. Agradecemos por disponibilizarem seu tempo e compartilharem seus saberes conosco. Também gostaríamos de agradecer a todas e todos os colegas do Projeto Botos da Barra (CECLIMAR/ CLN/UFRGS) que vêm contribuindo nos estudos sobre a pesca cooperativa na região. E. Silva agradece à PROREXT/ UFRGS pela concessão de uma bolsa de extensão. F. Abreu agradece ao CNPq pela concessão de uma bolsa de pós-doutorado - para realizar a pesquisa. O Projeto Botos da Barra contou com financiamento da Petrobrás S/A. Este trabalho é uma contribuição do Grupo de Pesquisa "Evolução e Biodiversidade de Cetáceos/ CNPq".

\section{Referências}

Ahearn, L. M. Agency. Journal of Linguistic Anthropology, 9(1-2), 12-15, 2000.

Berque, A. El pensamento paisajero. Madrid: Biblioteca NOVA, 2009.

Brasil. Decreto $\mathrm{n}^{\circ}$ 6.972, de 29 de setembro de 2000. Regulamenta a Lei ${ }^{\circ} 10.683$, de 28 de maio de 2003, que dispõem a Instrução Normativa MPA N ${ }^{\circ} 6$ de 29 de junho de 201. Brasília: DOU de 30/03/2020.

Cabral, L. O. A paisagem enquanto fenômeno vivido. Geosul, 15(30), 34-45, 2000.

Camargo, Y. R. R. A percepção ambiental dos usuários da barra do Rio Tramandai sobre o boto-da-barra, Tursiops sp. (Cetartiodactyla: Delphinidae). Porto Alegre,Trabalho de Conclusão de Curso (Graduação em Ciências Biológicas) - UFRGS, 2014.
Camargo, Y. R. R. Avaliação dos impactos ambientais de Projetos de pontes Rodoviárias no estuário do Rio Tramandaí, Sul do Brasil. Porto Alegre, Dissertação (Mestrado em Zoologia) - UFRGS, 2019.

Camargo, Y. R. R. de; Dal Forno, M. A. R.; Dorneles, D. R.; Frainer, G.; Ilha, E. B.; Rigon, C. T.; Santos, B.; Santos, M.L.; Serpa, N.; Simas, T. P.; Carlos, C. J.; Moreno, I. B. Diagnóstico ambiental do estuário do rio Tramandaí, litoral norte do Rio Grande do Sul, Brasil. Revista CEPSUL-Biodiversidade e Conservação Marinha, 9, 1-18, 2020.

Castro, D.; Mello, de, R. S.P. Atlas ambiental da bacia hidrográfica do Rio Tramandaí. Porto Alegre: Via Sapiens, 2013.

Cardoso, E. S. Territórios pesqueiros: conflitos e possibilidades para a gestão da pesca. São Paulo/SP, Revista Geousp, 14, 119-125, 2003.

Catão, B.; Barbosa, G. C. "Good dolphins", fishes and fishermen: about the conjoint fishing in Laguna (Santa Catarina, Brazil). Revista do Instituto de Estudos Brasileiros, 69, 205-225, 2018.

CEPSUL - Centro Nacional de Pesquisa e Conservação da Biodiversidade Marinha do Sudeste e Sul. IBAMA/ ICMBio. Relatório da reunião técnica para o ordenamento da pesca da tainha (Mugilplatanus, M. liza) na região sudeste/sul do Brasil, 2007. Disponível em: https://www. icmbio.gov.br/cepsul/images/stories/biblioteca/download/ relatorio_de_ordenamento/tainha/rel_2007_abr_tainha.pdf Acesso em: dez. 2020.

Certeau, M. A invenção do cotidiano: 1 . Artes de fazer. Petrópolis: Vozes, 1994. (título original 1980)

Cypriano-Souza, A. L.; de Meirelles, A. C.; Carvalho, A. C. O.; Bonatto, V. L.; Bonatto, S. L. Rare or cryptic? The first report of an Omura's whale (Balaenoptera omurai) in the South Atlantic Ocean. Marine Mammal Science, 33(1), 80-95, 2017.

Collot, M. Pontos de vista sobre a percepção das Paisagens. Boletim de Geografia Teorética, 20(39), 22-31, 1990.

Connor, R. C.; Heithaus, M. P.; Berggren, P.; Miksis, J. L. "Kerplunking": surface fluke-splashes during shallow water bottom foraging by bottlenose dolphins. Marine Mammal 
Science, 16, 646-653, 2000.

Csordas, T. Corpo/significado/cura. Porto Alegre: UFRGS. 2008.

Deshayes, P. Agentivité, devenir-chasseur et affects. Agency, becoming-hunter and affects. Ateliers d'anthropologie, 39(2), 2013. Disponível em: https://ateliers.revues.org/9503

Diegues, A. C. Pescadores, camponeses e trabalhadores do mar. São Paulo: Ática, 1983.

Diegues, A. C. Os saberes tradicionais e a biodiversidade no Brasil. Brasília: Ministério do Meio Ambiente; São Paulo: USP, 2000.

Dooren, T.; Kirskey,E:; Münster, U. Estudos multiespécies: cultivando artes de atentividade. ClimaCom, 3(7), 39-66, 2016.

Dos Santos, M. L. A importância da tainha (Mugil liza) na pesca entre golfinhos (Tursiops truncatus) e pescadores de tarrafa em Tramandai, RS. Tese, (Doutorado em Oceanografia Biológica) - FURG, 2016.

Eckert, C. As variações"paisageiras” na cidade e os jogos da memória. In: Silveira, F. L. A. da; Cancela, C. D. (Orgs.) Paisagem e cultura: dinâmica do patrimônio e da memória na atualidade. Belém: EDUFPA, 2009.

Ferreira, A. B. Holanda. De. Novo dicionário da Língua Portuguesa. Rio de Janeiro: Nova Fronteira, 1984.

Frank, K. Agency. Anthropological Theory, 6(3), 281-302, 2006.

Geertz, C. A interpretação das Culturas. Rio de Janeiro: LTC, 2008.

Giacomo, A. B. Análise do padrão de ocupação dos botos, Tursiops truncatus (Montagu, 1821), no estuário de Tramandai, sul do Brasil, a partir do estudo de fotoidentificação. Porto Alegre, Trabalho de Conclusão de Curso (Graduação em Ciências Biológicas) - UFRGS, 2014.

Giacomo, A. B.; Ott, P. Long-term site fidelity and residency patterns of bottlenose dolphins (Tursiops truncatus) in the Tramandaí Estuary, southern Brazil. Latin American Journal of Aquatic Mammals, 11(1-2), 155-161, 2017.

Guinet, C. Intentional stranding apprenticeship and social play in killer whales (Orcinus orca). Canadian Journal of Zoology, 69, 2712-2716, 1991

Haimovici, M.; Andriguetto-Filho, J. M.; Martins, A. S.; Victoria, I. A pesca marinha e estuarina do Brasil no início do século XXI: recursos, tecnologias, aspectos socioeconômicos e institucionais. Belém: Editora Universitaria UFPA, 2006

Harayashiki, C. A. Y.; Furlan, F. M.; Vieira J. P. Perfil sócio-econômico dos pescadores da Ponte dos Franceses, Rio Grande, RS, Brasil. Boletim do Instituto da Pesca, 37(1), $93-101,2011$.

Herbst, D. F.; Hanazaki, N. Local ecological knowledge of fishers about the life cycle and temporal patterns in the migration of mullet (Mugil liza) in Southern Brazil. Neotropical Ichthyology, 12(4), 879-890, 2014.

Hoelzel, A. R. Killer whale predation on marine mammals at Punta Norte, Argentina: food sharing, provisioning and foraging strategy. Behavioral Ecology and Sociobiology, 29, 197-204, 1991.

Ilha, E. B. Pescadores e botos: histórias de uma conexão em rede. Porto Alegre, Trabalho de Conclusão de Curso (Graduação em Ciências Biológicas) - UFRGS, 2016.

Ilha, E. B.; Serpa, N. B.; Santos, B.; Foleto, P. G.; Heissler, V. L.; Dorneles, D.R.; Camargo, Y. R.; Rigon C. T.; Santos M. L.; Gass C. M.; Calabrezi, R;, Kindel, E.A.I.; Moreno, I. B. Guia de apoio pedagógico para educadores: interação entre pescadores, botos e tainhas: aprendizados sobre cooperação, tradição e cultura. Porto Alegre: UFRGS, 2018.

Ingold, T. The perception of environment: Essays on Livelihood, Dwelling and Skill. Londres: Routledge, 2000.

Kumar, A. B.; Smirithy, R.; Sathasivam, K. Dolphin assisted cast net fishery in the Ashtamudi Estuary, southwest coast of India. Indian Journal of fisheries, 59, 143-148, 2012.

Laland, K. N.; Galef, B. G. The question of animal culture. Massachusetts: Harvard University Press, 2009.

Lemos, V. M.; Varela Jr, A. S.; Schwingel, P. R.; Muelbert, J. H.; Vieira, J. P. Migration and reproductive biology of Mugil liza (Teleostei: Mugilidae) in south Brazil. Journal of Fish Biology, 85(3), 671-687, 2014. 
Lopes, R. C. A pesca artesanal da tainha Mugil liza na Lagoa dos Patos, Rio Grande do Sul, brasil: um enfoque etnoictiologico. Rio Grande, Monografia (Graduação em Ciências Biológicas) - FURG, 2014

Mann, J.; Sargeant, B. L. Like mother, like calf: the ontogeny of foraging traditions in wild Indian Ocean bottlenose dolphins (Tursiops sp.). In: Fragaszy, D. M.; Perry, S. The biology of traditions: models and evidence. Cambridge: Editora, Cambridge University Press, p. 236-266, 2003.

Marques, O. R. A Barra Do Rio Tramandaí a partir dos olhos dos Pescadores Artesanais. In: RAM- Reunión de Antropología del Mercosur. Argentina, 4 a 7 de dez, 2017.

Medeiros, R. P. Estratégias de pesca e uso dos recursos em uma comunidade de pescadores artesanais da praia do Pântano do Sul (Florianópolis, Santa Catarina). Campinas, Dissertação (Mestrado em Ecologia) - Unicamp, 2001.

Minayo, M. C. S. O desafio do conhecimento: pesquisa qualitativa em saúde. São Paulo: Hucitec, 2001.

Miranda, A.; Vieira, L. de; Oliveira, F. de; Sousa, G.P. de; Fruet, P.F.; Zanoni, S.; Aparecida, S. Guia Ilustrado de Identificação de Cetáceos e Sirênios do Brasil. Brasília: ICMBio/CMA, 2019.

Monteiro, D. S. Encalhes e interação de tartarugas marinhas com a pesca no litoral do Rio Grande do Sul. Rio Grande, Monografia (Graduação em Biologia) - FURG, 2004.

Moreno, I. B.; Tavares, M.; Danilewicz, D.; Ott, P. H.; Machado, R. Descrição da pesca costeira de média escala no litoral norte do Rio Grande do Sul: comunidades pesqueiras de Imbé/Tramandaí e Passo de Torres/Torres. Boletim do Instituto de Pesca, 35(1), 129-140, 2009.

Pereira, R. C. Nécton marinho. In: Soares-Gomes, A.(org.) Biologia Marinha. Rio de Janeiro: Editora: Interciência, p. 158-193, 2002.

Peterson, D.; Hanazaki, N.; Simões-Lopes, P. C. Natural resource appropriation in cooperative artisanal fishing between fishermen and dolphin (Tursiops truncatus) in Laguna, Brazil. Ocean \& Coastal Management, Augustinusga, 51(6), 469-475, 2008.

Piola, A. R.; Matano, R. P.; Palma, E. D.; Moller, O. O.; Campos, E.J. The influence of the Plata River discharge on the western South Atlantic shelf. Geophysical Research Letters, 32, L01603, 2005.

Polit, D. F.; Becker, C. T.; Hungler, B. P. Pesquisa em enfermagem: métodos, avaliação e utilização. Porto Alegre: Artmed. 2004.

Rendell, L. E.; Whitehead, H. Culture in whales and dolphins. Behavioral and brain sciences, 24, 309-324, 2001.

Ronai, M. Paysages. Hérodote: Revue de géopolitique de l'agriculture, 1, 125-159, 1976.

Rossback, K.; Herzing, D. L. Underwater observations of benthic-feeding bottlenose dolphins (Tursiops truncatus) near Grand Bahama Island, Bahamas. Marine Mammal Science, 13, 498-504, 1997.

Sansot. P. Variations paysagères. Paris: Payot, 1983.

Santos, B. Identificação dos indivíduos da população de golfinhos do gênero Tursiops (Gervais 1855) no estuário do Rio Tramandai, Rio Grande do Sul. Porto Alegre, Trabalho de Conclusão de Curso (Graduação em Ciências Biológicas) - UFRGS, 2016.

Santos, M. L.; Lemos, V. M.; Vieira, J. P. No mullet, no gain: cooperation between dolphins and cast net fishermen in southern Brazil. Zoologia (Curitiba), 35, 12-31, 2018.

Sargeant, Brooke L. Mann, J.; Berggren, P.; Krtzen, M. Specialization and development of beach hunting, a rare foraging behavior, by wild bottlenose dolphins (Tursiops sp.). Canadian Journal of Zoology, 83(11), 1400-1410, 2005

Seelinger, U.; Costa, C. S. Os ecossistemas costeiro e marinho do extremo sul do Brasil. Rio Grande: Ecoscientia. 1998.

Serpa, N. B. Além das raizes culturais: as habilidades de caça de golfinhos cooperativos do sul do brasil. Porto Alegre, Dissertação. (Mestrado em Zoologia) - UFRGS, 2019.

Silveira, D. T.; Córdova, F. P. A pesquisa científica: Métodos de pesquisa. Porto Alegre: UFRGS. 2009.

Silveira, F. L. A. da. As paisagens coexistenciais interespecíficas, ou sobre humanos e não humanos compartilhando espaços domésticos numa cidade amazônica. Iluminuras, 17(42), 288-315, 2016. 
Simmel, G. A Filosofia da Paisagem. João Pessoa: UFPB, 1996.

Simões- Lopes, P. C. Interaction of coastal populations of Tursiops truncatus (Cetacea, Delphinidae) with the mullet artisanal fisheries in Southern Brazil. Biotemas. 4(2), 8394, 1991.

Simões-Lopes, P. C.; Fabián, M. E.; Menegheti, J. O. Dolphin interactions with the mullet artisanal fishing on southern Brazil: a qualitative and quantitative approach. Revista Brasileira de Zoologia, 15(3), 709-726, 1998.

Smith, B. D.; Tun, M. T.; Chit, A. M.; Win, H.; Moe, T. Catch composition and conservation management of a human-dolphin cooperative cast-net fishery in the Ayeyarwady River. Myanmar. Biological Conservation, 142(5), 1042-1049, 2009.

Spinelli, L. H. P.; de Jesus, A. H.; Nascimento, L. F.; Yamamoto, M. E. Prey-transfer in the marine tucuxi dolphin, Sotalia fluviatilis, on the Brazilian coast. Marine Biodiversity Records, 1, 3, 2008.

Tabajara, L. Aspectos da relação pescador-boto-tainha no estuário do Rio Tramandaí- RS. Concurso Botos do rio Tramandaí: trabalhos premiados. Tramandaí: Editora Suliani,1993.

Terceiro, A. M. Conhecendo a pesca artesanal em Tramandaí e Imbé-RS: Distribuição espacial e desafios. Ciência e Natura, 39(2), 341-351, 2017.

Taylor, C. S.; Carter, J. The Agency of Dolphins: Towards Inter-species Embassies as Sites of Engagement with 'Significant Otherness'. Geographical Research, 51(1), 1-10, 2012.

Tuan, Yi-Fu. Espaço \& Lugar. A Perspectiva da Experiência. São Paulo: DIFEL, 1983.
Velho, G. Observando o familiar. A aventura sociológica. Rio de Janeiro: Zahar, 36-46, 1978.

Vermeulen, E.; Fruet, P.; Costa, A.; Coscarella, M.; Laporta, P. 2019. Tursiops truncatus ssp. gephyreus. The IUCN Red List of Threatened Species, 2019. Disponível em: $<$ https://www.researchgate.net/profile/Pedro_Fruet3/ publication/339031974_Vermeulen_Fruet_et_al_IUCN Gephyreus/links/5e39d174458515072d800fd2/Vermeulen-Fruet-et-al-IUCN-Gephyreus.pdf $>$. Acesso em: ago. 2020.

Vieira, J. P.; Scalabrin, C. Migração reprodutiva da "tainha" (Mugil platanus Gunther, 1980) no sul do Brasil. Atlântica, 13, 131-141, 1991.

Vieira, J. P.; Garcia, A. M.; Moraes, L. O Estuário da Lagoa dos Patos: um século de transformações. A assembleia de peixes. In: Seeliger, U.; Odebrecht, C. (Orgs.). Rio Grande: FURG, p. 79-88, 2010.

Vieira, J. P. Distribuição, abundância e alimentação dos jovens de Mugilidae no estuário da Lagoa dos Patos, e movimentos reprodutivos da "tainha" Mugil platanus Günther, 1880 no litoral sul do Brasil. Rio Grande, Tese (Doutorado em Oceanografia Biológica) - FURG, 1985.

Wickert, J. C.; Von Eye, S.; M, Oliveira L.R.; Moreno I. B. Revalidation of Tursiops gephyreus Lahille, 1908 (Cetartiodactyla: Delphinidae) from the southwestern Atlantic Ocean. Journal of Mammalogy, 97(6), 1728-1737, 2016.

Wüudig, N. L.; Freitas, S. M. F. de. Ecossistemas e biodiversidade do Litoral Norte do RS. Porto Alegre: Nova Prova, 2009.

Zappes, C. A.; Andriolo, A.; Simões-Lopes, P. C.; Di Beneditto, A. P. M. 'Human- dolphin (Tursiops truncatus, Montagu, 1821) cooperative fishery and its influence on cast net fishing activities in Barra de Imbé/ Tramandaí, Southern Brazil. Ocean \& Coastal Management, 54, 427-432. 2011. 